\title{
Эффективные методы контроля формы поверхности компонент флип-чип фотоприёмников
}

\author{
А.Р. Новоселов ${ }^{1}$, П.А. Алдохин ${ }^{1}$, А.Е. Маточкин ${ }^{2}$, П.П. Добровольский ${ }^{1}$, К.П. Шатунов ${ }^{1}$ \\ ${ }^{1}$ Филиал ИФП СО РАН «КТИПМ», г. Новосибирск, 630090, пр-кт Академика Лаврентьева, 2/1 \\ тел. (383) 330-97-49, эл. почта: novoselov@isp.nsc.ru \\ ${ }^{2}$ Институт автоматики и электрометрии СО РАН, г. Новосибирск, 630090, пр-кт Академика \\ Kоптюга,1,эл. почта: matochkin@iae.nsk.ru
}

DOI 10.34077/RCSP2019-139

Исследована возможность применения автоколлимационного и интерференционного методов для неразрушающего оперативного контроля формы поверхностей фотоприёмников, изготовленных гибридизацией («Flip-chip» технология), и их компонент. Методы позволяют контролировать формы поверхностей и стрелки прогиба. Этими методами были исследованы: формы поверхностей фрагментов кремниевых приборных пластин и матриц фоточувствительных элементов на подложках GaAs; формы поверхностей фотоприёмников на разных стадиях разрушения и в процессе термоциклирования.

При проведении исследований выяснено, что форма поверхности всегда отличается от плоской. Каждый чип даже на одной приборной пластине, после её разделения, имеет свою форму поверхности. В таблице, для примера, приведены результаты исследования автоколлимационным и интерференционным методами двух фрагментов кремниевой приборной пластины после её разделения.

\begin{tabular}{|c|c|c|c|c|c|}
\hline \multicolumn{3}{|c|}{ Интерференционный метод } & \multicolumn{3}{|c|}{ Автоколлимационный метод } \\
\hline \multicolumn{2}{|c|}{$\begin{array}{c}\text { Среднее значение } \\
\text { стрелки прогиба, } \\
\text { мкм }\end{array}$} & \multirow[t]{2}{*}{ Примечание } & \multicolumn{2}{|c|}{$\begin{array}{c}\text { Среднее значение } \\
\text { стрелки прогиба, } \\
\text { мкм }\end{array}$} & \multirow[t]{2}{*}{ Примечание } \\
\hline$H_{2 o p}$ & $H_{\text {вepm }}$ & & $H_{\text {гор }}$ & $H_{\text {вepm }}$ & \\
\hline 3,18 & $-1,47$ & $\begin{array}{c}\text { Планарная сторона } \\
\text { Пиковое значение по образцу } \\
4,81 \text { мкм }\end{array}$ & $-3,25$ & $-0,5$ & $\begin{array}{c}\text { Выпуклая с планарной } \\
\text { стороны, размер 20х20 мм, } \\
\text { тыльная сторона } \\
\text { шлифована, одна, край } \\
\text { пластины. }\end{array}$ \\
\hline 1,41 & $-2,43$ & $\begin{array}{c}\text { Планарная сторона } \\
\text { Пиковое значение по образцу } \\
\text { 4,90 мкм }\end{array}$ & 0,66 & $-1,96$ & $\begin{array}{c}\text { Вогнуто-выпуклая с } \\
\text { планарной стороны, размер } \\
\text { 20х20 мм, тыльная сторона } \\
\text { шлифована, , центр } \\
\text { пластины, образец имеет } \\
\text { сложную форму }\end{array}$ \\
\hline
\end{tabular}

Проведённые исследования по применению известных методов измерении кривизны объектов показали их эффективность применения в технологии изготовления ФП. Применение этих методов исследования формы поверхностей компонент фотоприёмников улучшит долговечность работы фотоприёмников. 